\title{
Innovation in Sustainable Education and Entrepreneurship through the UKM Recycling Center Operations
}

\author{
Shahrom Md Zain ${ }^{1}$, Noor Ezlin Ahmad Basri ${ }^{1}$, Nur Ajlaa Mahmood ${ }^{1}$, Hassan Basri ${ }^{1}$, Mashitoh Yaacob ${ }^{2}$ \& \\ Maisarah $\mathrm{Ahmad}^{3}$ \\ ${ }^{1}$ Department of Civil and Structural Engineering, Faculty of Engineering \& Built Environment, Universiti \\ Kebangsaan Malaysia, Selangor, Malaysia \\ ${ }^{2}$ Centre of General Studies, Universiti Kebangsaan Malaysia, Selangor, Malaysia \\ ${ }^{3}$ Faculty of Economy and Management, Universiti Kebangsaan Malaysia, Selangor, Malaysia \\ Correspondence: Shahrom Md Zain, Department of Civil and Structural Engineering, Faculty of Engineering \& \\ Built Environment, Universiti Kebangsaan Malaysia, 43600 UKM Bangi, Selangor, Malaysia. Tel: \\ 60-389-218-338. E-mail: smz@eng.ukm.my
}

\author{
Received: February 7, 2013 Accepted: February 26, 2013 Online Published: May 30, 2013 \\ doi:10.5539/ies.v6n6p168 \\ URL: http://dx.doi.org/10.5539/ies.v6n6p168
}

\begin{abstract}
Sustainable education and entrepreneurship through practical learning activities are necessary for students in higher education institutions. Students must experience real situations to develop an attitude and personality of caring for the environment, and they can acquire entrepreneurship education by managing transactions with recyclables. The research group for the initiative for a zero-waste UKM campus has recognized the need for students from all levels to become involved in the management of UKM Recycling Center operations. The MegaGreen Solution company, established by five master's students from the Faculty of Engineering and Built Environment, has operated the UKM Recycling Center with the help of 69 undergraduate students from the general university courses Self-Development (ZT1052) and Users' Behavior (EPPM3113). The UKM Recycling Center operations provide students with experience to trigger their creativity and entrepreneurship knowledge and to increase their awareness of recycling activities. This article discusses the problems that occur in UKM Recycling Center operations and how these problems are improved by students' involvement. The percentages of recyclables in the first three years of operations (April to July 2010 to 2012) were 1.68\% in 2010, 2.18\% in 2011, and $2.38 \%$ in 2012 , with increasing numbers of users of the center, to eight persons per week. This is an early indicator of accomplishment for the students' management operations. A pioneering survey showed that the majority of students involved in the program have been encouraged to think more creatively, innovatively and critically.
\end{abstract}

Keywords: innovation, education, sustainability, entrepreneurship, the UKM recycling center

\section{Introduction}

Unemployment can prevent graduates from pursuing careers in their respective fields, but it is the responsibility of graduates to avoid limiting the opportunities available to them. Graduates can discover opportunities in entrepreneurship without depending on job opportunities in their respective fields of study. However, does entrepreneurship knowledge prepare graduates to be involved in their fields? The Ministry of Higher Education has given extra attention to entrepreneurship in higher learning as the catalyst for the National Transformation agenda by encouraging entrepreneurship education in the teaching and learning process in both formal and informal courses in higher learning institutions across fields of study. Entrepreneurship complements innovation and is a process of research transformation that encourages innovation to produce business activities that produce profits and value. Innovation is wasted if it remains only innovation (Mohd Khalid, 2012). Mohamed Khalid (2009) said that the development of an entrepreneurship culture among the new generation through a national education system and religious studies is a prerequisite. It is important for Muslims to develop and utilize strength in economics and business.

Siti Hawa's (2009) research on the entrepreneurial tendency among engineering students in higher learning institutions in the North of Peninsular Malaysia found that most engineering students have a tendency toward 
entrepreneurship. If they receive support, encouragement and exposure, there is a higher possibility that they will become entrepreneurs after they graduate. Nor Aishah Buang's (2008) research suggests the need for formal entrepreneurship education for UKM students, especially students in the Engineering and Built Environment Faculty and the Education Faculty. That study suggested that formal entrepreneurship education can encourage students from both faculties to consider entrepreneurship as a career. Beginning in 2011, first-year students in their second semester in the Engineering and Built Environment Faculty at UKM were introduced to a two-credit-hour entrepreneurship course, which is known as The Basics of Entrepreneurship and Innovation and is conducted by the Centre for Entrepreneurship and SME Development (CESMED). Innovation and creativity are important components that are prioritized in the engineering teaching and learning process. Unfortunately, there are no formal courses that focus on innovation and creativity in the Engineering and Built Environment Faculty. A study was conducted by Afida Ayob, Aini Hussain, Mohd Marzuki Mustaffa and Rosadah Abdul Majid (2011) to assess the creativity of Electrical and Electronics Engineering students using the Torrance Test for Creative Thinking. The test was given to students representing UKM in a national competition to design robots. The results indicated that more than half of the students had above-average creativity scores. Research by Jaafar et al (2009) on students' creativity in solving problems such as mechanical engineering design projects showed that students failed to provide thoughtful and creative ideas in these projects. Without a formal course that teaches creativity, it may be difficult for students to develop a cognitive level related to creativity.

Given the importance of innovation, entrepreneurship and sustainable education in the author's involvement in teaching and learning at UKM and in research on the UKM Recycling Center activities, the author intended to combine the components of sustainability and entrepreneurship with a focus on 3R (Reduce, Reuse \& Recycle) innovations via UKM Recycling Center operations. The combination of research and teaching has beneficial implications for the teaching and learning process. The involvement of Alam Flora Sdn Bhd, the Centre for Entrepreneurship and SME Development (CESMED) and the Department of Development \& Maintenance UKM have been very helpful. The topic that will be discussed in this paper is the combination of $3 \mathrm{R}$ innovation and sustainable entrepreneurship education in the teaching and learning process. The author has written previous papers on her experience with sustainable education with a focus on environmental components in the teaching and learning process (Shahrom Md Zain et al 2008, Shahrom et al 2009, Shahrom et al 2010 \& Shahrom et al 2011), which can be used in the educational process of teaching and learning. These writings do not address students' innovation and creativity. Improvements in the teaching and learning process should be examined in the context of national education transformations.

Innovation in engineering education has been successful until the commercialization stage. Students from the Electric and Electronic Engineering Department in the Engineering and Built Environment Engineering Faculty UKM who have demonstrated their innovative development of Green Technology and Power Conservation through Use of Intelligent Systems are capable of obtaining copyright protection and commercialization (UKM News Portal 2012). Liebenberg and Mathews (2012) have noted that first-year engineering courses at the University of Pretoria, South Africa have been improved through their incorporation of innovative and entrepreneurial issues. The design-build-innovate course requires students to solve problems in a group creatively, to consider the need for copyright for the project and to prepare a business plan. The students also engage in competition at the university and national levels. The work of these students has been successfully patented and can be used to develop small-scale companies. Radharamanan and Juang (2012) prioritized the need for entrepreneurship and innovation in engineering education at the Mercer University School of Engineering in the US through a tabletop design project retrofitting CNC Lathe. Duval-Couetil et al (2012) reported a survey of 501 senior engineering students from three universities who had attended the Capstone design courses entrepreneurship program found that there is a two-thirds or more of students will choose careers in large and medium-sized companies after graduation with the same amount of students felt that entrepreneurship education give bigger opportunities and greater choices for their career. Students who have taken one or more entrepreneurship courses have higher levels of entrepreneurial ability. Thus, formal or informal entrepreneurship courses in engineering education can provide a wide range of career choices for graduate students.

How can the process of teaching and learning innovations be accomplished? Is there a method or model that can be used? Sandberg and Ohman (2011) discuss a framework for a conceptual model of innovation learning (theoretical and practical) that includes the main components of product development innovation, ideas and business, information, marketing finance, consulting, contracts and copyright protection. According to these authors, students learn through experience. The authors believe that students need to experience these situations to create innovations and to develop creativity that arises from problems. 
Zaini (2010) referred to the question of sustainable key innovations and argued that sustainability is a universal need, not only to ensure the environment is protected but also to facilitate stable economic growth and to meet human needs. Indicators of success can be found in data and statistical economic reports as well as in the ability to create an environmentally friendly culture, values and society. Key environmental sustainability should be included in engineering education innovation. Zaini (2009) discussed the RM1 billion transactions related to solid waste, focusing on the high cost required to manage solid waste in technical terms. He suggested that it is appropriate to classify solid waste as a source so that potential resources for trash can be evaluated and used depending on the nature and amount of content. Providing engineering and science innovations and entrepreneurship to these sources can reduce management costs. The Law of Solid Waste Management and Public Cleansing were expected to be implemented in September 2012 to support the need for entrepreneurial innovation recycling.

\section{The Development of Entrepreneurship and Sustainability Education Modules}

This research intended to develop entrepreneurship and sustainability education modules with a combination of entrepreneurship and education research through UKM Recycling Center operations. The module focuses on the elements of innovation and creativity to enhance the management system based on existing problems. There are three (3) research phases:

First phase: The establishment of the MegaGreen Solution to operate the UKM Recycling Center. This includes research on $3 \mathrm{R}$ commercial opportunities, business plan preparation and marketing strategies by the established company. It involves cooperation between the Faculty of Engineering \& Built Environment (FKAB), the Faculty of Economy \& Management (FEP), the Center of General Studies (PPU) and the Institute of Environment \& Sustainable Development (LESTARI). To ensure that the UKM Recycling Center entrepreneurship operations do not clash with UKM policies, understanding between the treasury department, the department of maintenance and development and the Center of Entrepreneurship for SME Development (CESMED).

Second phase: This phase involves students from the Self Development course (PPU) and the User Behavior course (FEP) for UKM Recycling Center operations via the teaching and learning process. This phase includes a survey of students in the early and final stages of the program to determine students' acceptance and the effectiveness of the program. The arranged activities and programs support the learning outcomes of the courses, which focus on innovation and creativity.

Third phase: Measurement of the effectiveness and sustainability of the entrepreneurship education model.

This article discusses only the implementation stages for the first and second phases, which include solutions and improvements to UKM Recycling Center operations by students from the ZT1052 course (63 students) and EPPM3113 (6 students). A survey was conducted to determine students' early acceptance of the activities. This model is not restricted to students from the courses ZT1052 and EPPM3133; it can be used for other courses that are appropriate for the course outcomes.

\subsection{Education through the UKM Recycling Center Operation}

A proliferation of new ideas can be triggered through the platform at hand driven by the desire and the need for research that can be utilized by all. Many problems arise from recycling activities that require innovative and creative solutions involving various areas of research (Figure 1). This may include problems involving management systems, storage, the separation process, the low value of recyclables, transportation, lack of a workforce, publicity, awareness, and knowledge about the importance of recycling.

Problems in the UKM Recycling Center operations help students understand how their participation can help and how the teaching and learning process continued as usual. Figure 2 shows how a combination of innovation, sustainability and entrepreneurship is beneficial to research and teaching in UKM. The initial phases of this project are the establishment of a company and improvements to the recycling center management through the involvement of students from the university's general courses Self Development (ZT1052) and User Behavior (EPPM3113). 


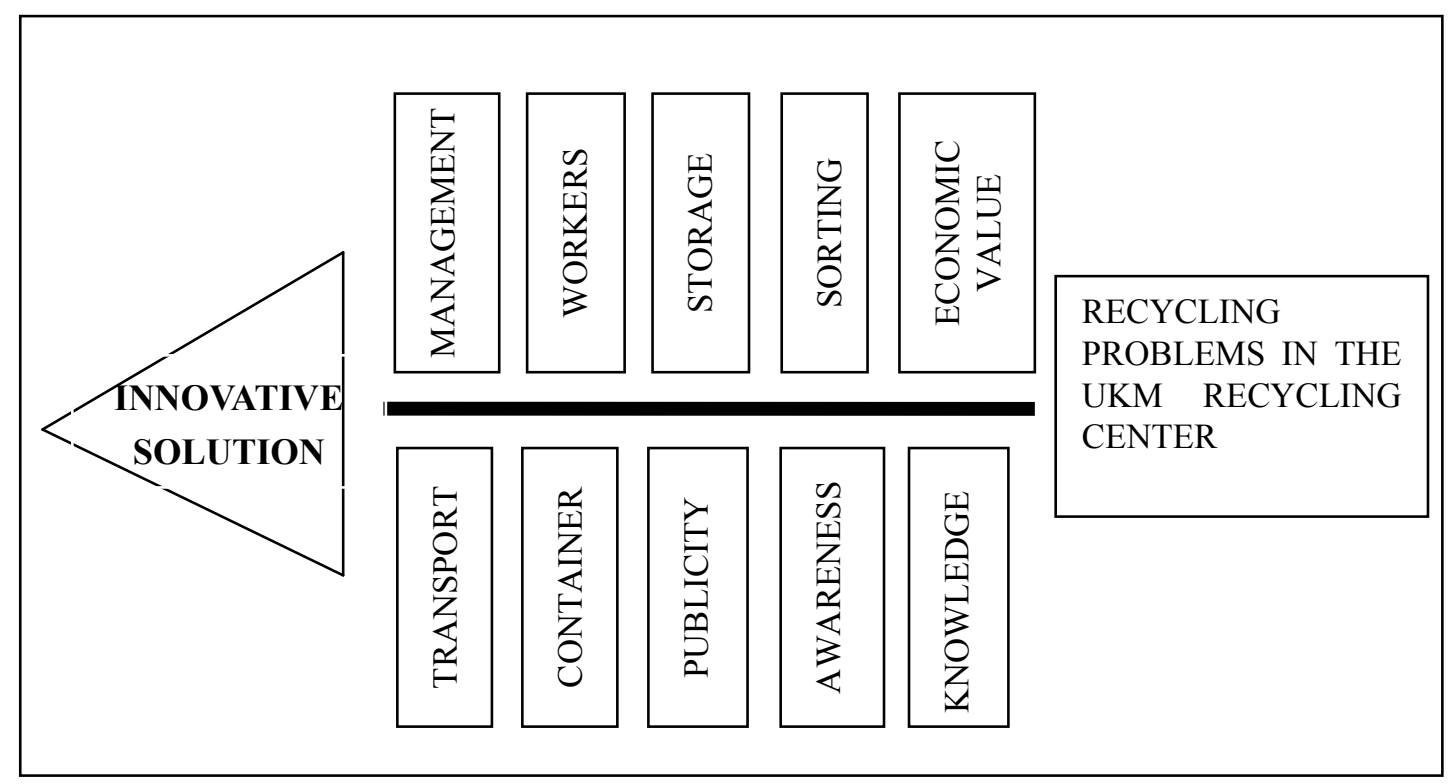

Figure 1. Innovative solutions to recycling problems

\begin{tabular}{|c|c|c|}
\hline & $\begin{array}{l}\text { THE UKM RECYCLING CENTER } \\
\text { (RESEARCH AND EDUCATION) }\end{array}$ & \\
\hline \multicolumn{3}{|r|}{$\nabla$} \\
\hline $\begin{array}{l}\text { INNOVATION } \\
\text { - } \quad \text { Efficient Management } \\
\text { - } \quad \text { Engineering design } \\
\text { (Increase recycling } \\
\text { values) } \\
\text { - Effectiveness of the } \\
\text { awareness program } \\
\text { - Teaching \& learning } \\
\text { methods }\end{array}$ & $\begin{array}{l}\text { SUSTAINABILITY } \\
\text { - Environmental } \\
\text { preservation through } \\
\text { solid waste } \\
\text { management toward } \\
\text { zero waste } \\
\text { - Sustainability } \\
\text { education }\end{array}$ & $\begin{array}{l}\text { ENTREPRENEURSHIP } \\
\text { - Increase income } \\
\text { - Knowledge of } \\
\text { entrepreneurship } \\
\text { - } \\
\text { Experience as an } \\
\text { entrepreneur } \\
\text { - } \quad \text { Soft skills (leadership } \\
\text { and communication) }\end{array}$ \\
\hline & - Sustainable behavior & \\
\hline
\end{tabular}

Figure 2. The benefits of the combination of innovation, sustainability and entrepreneurship in the UKM Recycling Center

\subsection{Establishment of Student's Company}

A company known as MegaGreen Solution was established by five master's students from the Faculty of Engineering and Built Environment UKM who were involved in solid waste management research projects and educational research, including managing $3 \mathrm{R}$ entrepreneurial activities at the UKM Recycling Center. The mentors are included five lecturers from for different sector involving lecturers from FKAB, FEP, PPU and LESTARI. Integration from these different sectors can help the student learned not only in the engineering part but also the environment, human behavior and business. These groups of students produced a business plan, 
created a marketing strategy and conducted research on 3R business opportunities. Their business strategy involves not only the sale of recyclables but also broader opportunities by providing a sustainable consultation service and sustainability education training modules for schools. Sekolah Rendah Islam As-Sofa, Bandar Baru Bangi Selangor was chosen to implement the sustainability education training modules (Figure 3). The management of the UKM Recycling Center began in January 2012 by this group of students. They have increased the number of customers and recyclables.
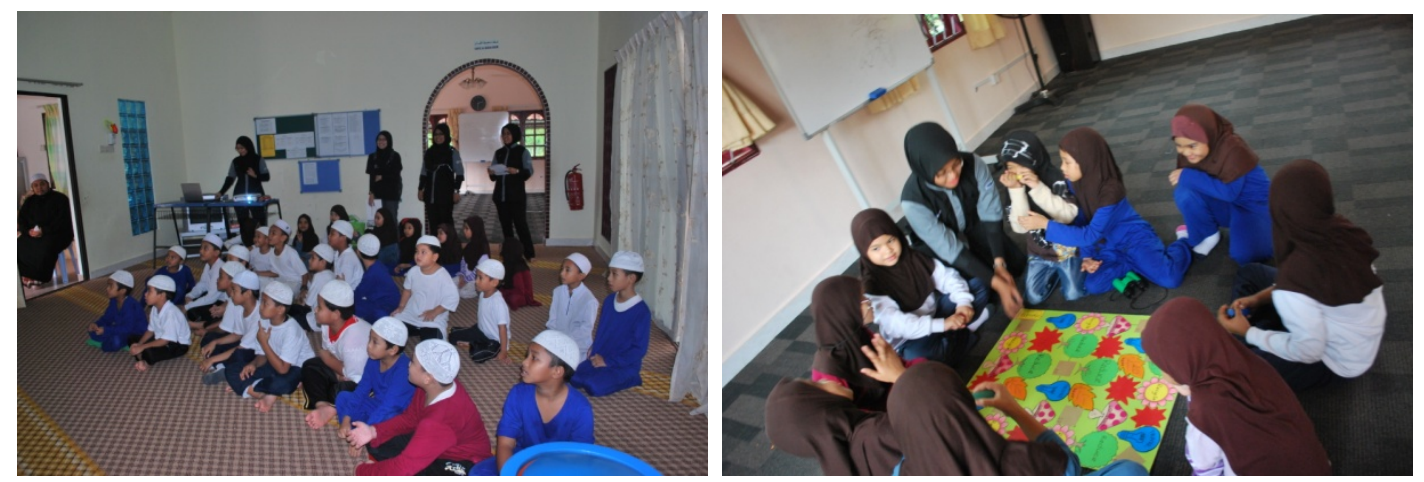

Figure 3. MegaGreen Solution at Sekolah Rendah Islam As-Sofa, Bandar Baru Bangi Selangor

Many techniques have been used to promote the UKM Recycling Center, such as advertisements, posters, talks, awareness workshops, and reminder emails to the UKM community. Continues reminder and promotion helps to remind the users and reduce the confusion on the center operation. Nevertheless, awareness and apprehension among students must be developed through the teaching and learning process.

\subsection{Undergraduate Student's Involvement and the Activities}

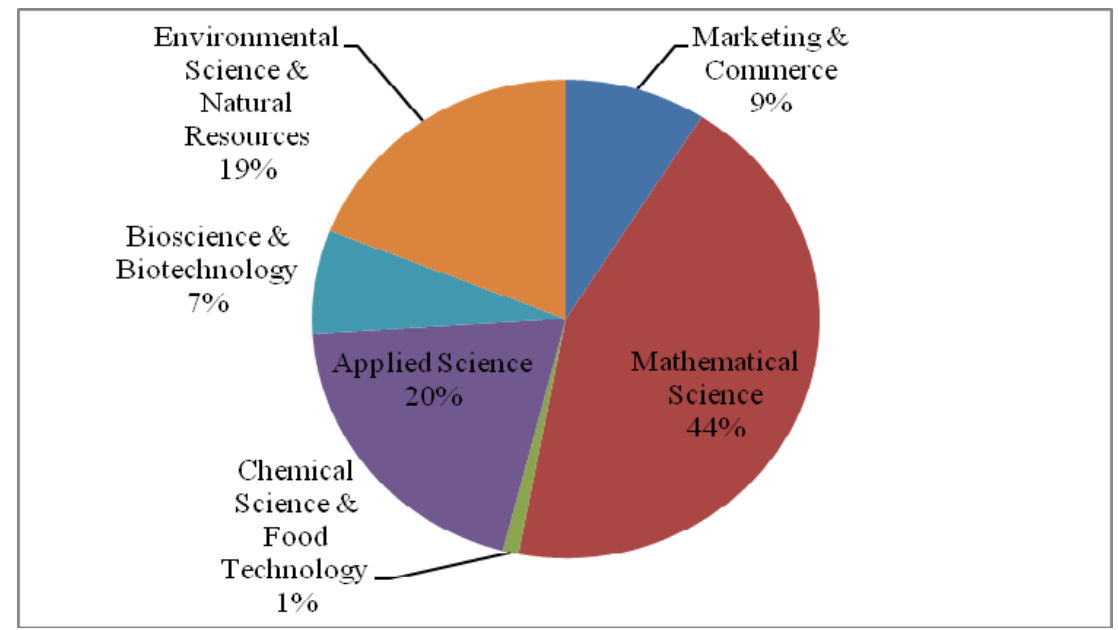

Figure 4. Percentage of students by program of study involved with activities at the UKM Recycling Center

To provide exposure and experience related to solid waste management to undergraduate students, the author worked with the zero waste research group and the MegaGreen solution to develop the UKM Recycling Center operational program with Year 1 students (63 students: 91.3\%) from various faculties who had taken a general university course (the Self Development course, ZT1052) and Year 3 students (6 students: 8.7\% in the User Behavior course (EPPM3113). In total, there were 69 students from different educational backgrounds (Figure 4). The students' involvement is one of the initiatives to promote the UKM Recycling Center and is part of the first phase of the UKM Recycling Center students' entrepreneurial project. It is intended to meet the teaching requirements for this course in terms of communication and the students' responsibility to care for the environment. Figure 5 shows the activities performed by students in the collection of office recycling papers, 
meetings and presentations. By using creativity and innovation, the students will attend workshops and carnivals and produce an activity report to be presented on the following activities:

- Survey: To what extent do the UKM communities know about UKM Recycling Center operations and their involvement in recycling activities?

- Marketing: Find ways to promote and publicize the UKM Recycling Center effectively

- UKM offices' paper collection: Collect papers produced by the offices. Students record the paper quantities, collection types, locations, dates and problems that arise.

- Attending environmental awareness workshop: Students use creativity to present the results of the activities.

- Zero-waste carnival and better green run, which provide opportunities to publicize the UKM Recycling Center.

- "Cherish the Environment Bestowed by the Creator" workshop: Be thankful and appreciate the nature gifted by God.
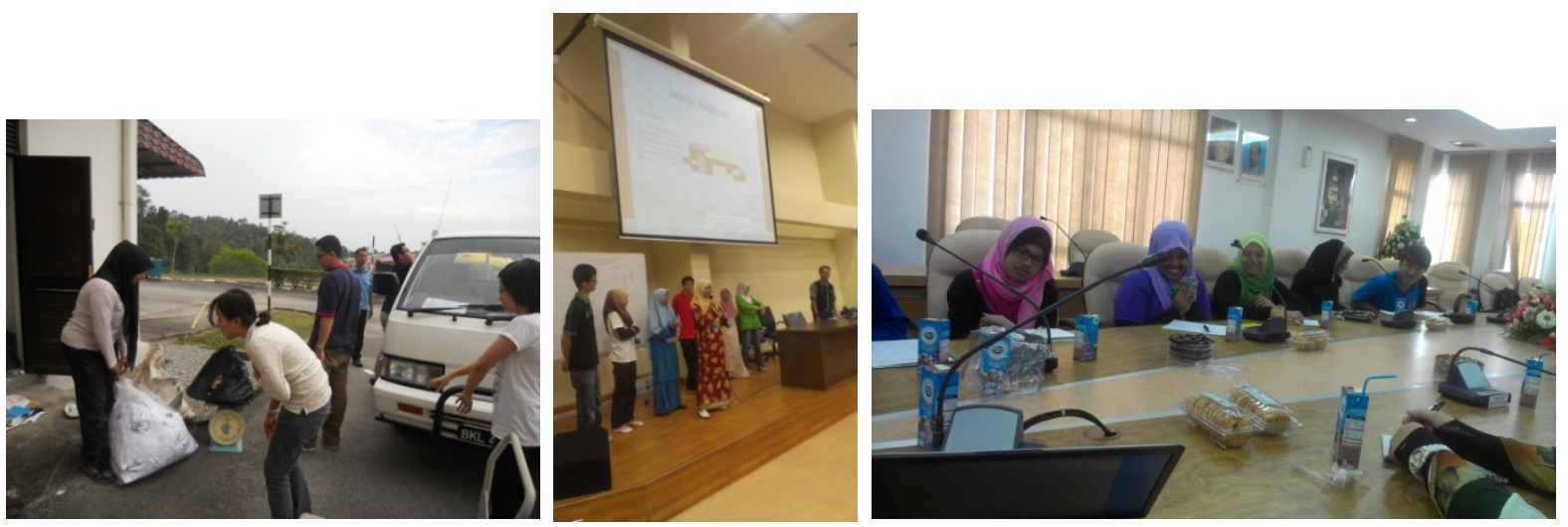

Figure 5. Student's activities

Study that been conducted from March to June 2012 by students is an interviewed, which the respondents are students, academician and non-academician from all various faculty. The interviews consist of three parts of questions, respondent's basic information, respondent's awareness of the recycling centre existence and suggestion on the centre's operation. The students successfully interviewed 89 respondents.

Table 1. Users awareness on the existence of UKM's Recycling Centre

\begin{tabular}{cccc}
\hline Questions & Students & Academician & Non-Academician \\
\hline Know the existence of UKM's Recycling Centre & 21 & 25 & 21 \\
\hline
\end{tabular}

Table 1 shown the first question in the second part of the interview which information about the respondent's awareness of the UKM's recycling centre existence. 75\% know about the existence of UKM's recycling centre. Most of the respondents aware of it due to the promotions and publicity that have been done.

Table 2. Users awareness on UKM's Recycling Centre location

\begin{tabular}{cccc}
\hline Questions & Students & Academician & Non-Academician \\
\hline Know the location of UKM's Recycling Centre & 20 & 11 & 18 \\
\hline
\end{tabular}

Table 2 is connected with the question in table 1 where even though $75 \%$ know about the centre but $83 \%$ do not know the location of the centre. Improvement will be made by the management to ensure full details are given to the users. 
Table 3. Users awareness of activities in UKM's Recycling Centre

\begin{tabular}{cccc}
\hline Questions & Students & Academician & Non-Academician \\
\hline Aware of UKM's Recycling Center activities & 6 & 7 & 9 \\
\hline
\end{tabular}

UKM's recycling centre had conducted a lot of activities such as zero waste carnival, buy-back recyclables, green competitions and many more but sadly only $25 \%$ aware of these activities, as shown in table 3 .

Table 4. Number of users using the UKM's Recycling Centre services

\begin{tabular}{cccc}
\hline Questions & Students & Academician & Non-Academician \\
\hline Using services that been provided by the centre? & 4 & 2 & 3 \\
\hline
\end{tabular}

The third part of the interview is usage of the centre and respondents suggestion. From table 1, we can see that $75 \%$ know about the centre but $10 \%$ had been use the service and facilities given. The reasons given by respondents that did not use the service are non-strategic location, do not do recycling, not aware about the centre, practicing recycling activities elsewhere, the centre operation's time is inconsistent and no authority to push them to recycle. Respondents also suggested the operation time to a longer period which can give them options to go to the centre.

Total results of the survey suggest that students from residential colleges should be considered in recycling activities. Thus, at this stage, efforts are underway to place mini-recycling centers in residential colleges to assist students in recycling activities. The results of the programs conducted with students demonstrate the amount of recyclables that were collected and users of the center. In the first three years of operations (April to July 2010 to 2012), the percentages of recyclables were $1.68 \%$ in $2010,2.18 \%$ in 2011 and $2.38 \%$ in 2012, with an increasing number of users to the center of 8 people per week. This is an early accomplishment indicator for the students' management operations that demonstrates the success of UKM Recycling Center operations in terms of total collection and operating times (Monday to Wednesday, 9:30am to 5:30pm).

\section{The Teaching and Learning Process at the UKM Recycling Center Triggers a Creative, Innovative and Critical Survey}

The next focuses involve the components of innovation and creativity in the learning process through the UKM Recycling Center activities. Critical thinking, creativity and innovativeness are skills that students need to solve problems and to trigger new and thoughtful ideas to produce something better. Research by Mohammad Yusof Arshad and Siti Hajar Alias (2011) showed that there is no significant difference between the level of creativity and the academic accomplishments of science students. This shows that it is not necessary to be a bright student with good academic achievement to have a high level of creativity. Creativity is influenced by many factors, including students' environment and social life. Yahaya Buntat and Noor Sharliana Mat Nasir (2011) found that the factors that influenced creativity among students at Universiti Teknologi Malaysia were knowledge, thinking style, personality, motivation and environmental conditions that encourage students' creativity. The major factor that influences students' creativity is knowledge. Hence, the effort to learn through UKM recycling operations may increase students' knowledge while creating an environment that can enhance their creativity level.

Acceptance by students is assessed through surveys to determine students' involvement in recycling activities and environmental programs, which can encourage students to think creatively, innovatively and critically. Students from course ZT1052 consist of various studies which is mathematical science; applied science; chemical science and food technology; bioscience and biotechnology; and environmental science and natural resources. While students from course EPPM3113 are majoring in marketing and commerce.

Table 5 presents the results of a study to determine whether the teaching and learning process boosts creativity, innovativeness and critical thinking among students in the ZT1052 and EPPM3113 courses. The results indicate that $76 \%$ of the ZT1052 course students and $67 \%$ of the students from EPPM3113 agreed and strongly agreed that the teaching and learning process encouraged them to think more creatively, innovatively and critically. From table $6,77 \%$ of the students from ZT1052 and 67\% of the students from EPPM 3113 agreed and strongly agreed that the assignment or project required them to examine ways to solve problems creatively. While table 7 , shows the results of a survey of students' acceptance of UKM Recycling Center activities and environmental 
programs that encourage them to think more creatively, innovately and critically. The results indicated that $80 \%$ of all students agreed and strongly agreed that their experience of recycling activities and environmental programs was enjoyable and encouraged them to become more creative and innovative. When the question was related to whether their involvement in recycling activities encouraged them to solve problems creatively in table $8,77 \%$ of all students agreed and strongly agreed. This finding shows that the majority of students agreed that the activities encouraged them to think more creatively, innovatively and critically.

Table 5. The teaching and learning process in this course encourages me to think innovatively, creatively and critically

\begin{tabular}{lccccc}
\hline Courses & Strongly Disagreed & Disagreed & Do not care & Agreed & Strongly Agreed \\
\hline ZT1052 & 0 & 4 & 11 & 33 & 15 \\
EPPM3113 & 0 & 0 & 2 & 4 & 0 \\
\hline Total (students) & $\mathbf{0}$ & $\mathbf{4}$ & $\mathbf{1 3}$ & $\mathbf{3 7}$ & $\mathbf{1 5}$ \\
\hline
\end{tabular}

Table 6. The assignments/projects required me to examine ways to solve problems creatively

\begin{tabular}{lccccc}
\hline Courses & Strongly Disagreed & Disagreed & Do not care & Agreed & Strongly Agreed \\
\hline ZT1052 & 1 & 1 & 8 & 41 & 12 \\
EPPM3113 & 0 & 0 & 2 & 4 & 0 \\
\hline Total (students) & $\mathbf{1}$ & $\mathbf{1}$ & $\mathbf{1 0}$ & $\mathbf{4 5}$ & $\mathbf{1 2}$ \\
\hline
\end{tabular}

Table 7. The experience involving recycling activities and environmental programs is enjoyable and encourages me to be more creative and innovative

\begin{tabular}{lccccc}
\hline Courses & Strongly Disagreed & Disagreed & Do not care & Agreed & Strongly Agreed \\
\hline ZT1052 & 0 & 1 & 10 & 31 & 21 \\
EPPM3113 & 0 & 0 & 3 & 3 & 0 \\
\hline Total (students) & $\mathbf{0}$ & $\mathbf{1}$ & $\mathbf{1 3}$ & $\mathbf{3 4}$ & $\mathbf{2 1}$ \\
\hline
\end{tabular}

Table 8. Involvement in recycling activities encourages my creativity for better problem solving

\begin{tabular}{lccccc}
\hline Courses & Strongly Disagreed & Disagreed & Do not care & Agreed & Strongly Agreed \\
\hline ZT1052 & 1 & 2 & 10 & 33 & 17 \\
EPPM3113 & 0 & 0 & 3 & 3 & 0 \\
\hline Total (students) & $\mathbf{1}$ & $\mathbf{2}$ & $\mathbf{1 3}$ & $\mathbf{3 6}$ & $\mathbf{1 7}$ \\
\hline
\end{tabular}

\section{Conclusion}

Entrepreneurship education is a way for students to diversify their career choices in many areas, including engineering. Innovation, sustainability, and 3R entrepreneurship through the operation of the UKM Recycling Center is the initial phase of the effort to provide opportunities and space for entrepreneurship and sustainability education for the UKM students. The survey showed that the majority of the students from both courses, ZT1052 and EPPM3113, agreed that the teaching and learning involved in UKM Recycling Center operations encouraged them to think more creatively, innovatively and critically. However, this model is not restricted to the ZT1052 and EPPM3113 courses. It can be used for other courses that are appropriate to the course outcomes.

\section{References}

Afida Ayob, Aini Hussain, Mohd Marzuki Mustaffa, \& Rosadah Abdul Majid. (2011). Penilaian kreativiti dalam kejuruteraan elektrik. Kongres Pengajaran \& Pembelajaran UKM2011. Universiti Kebangsaan Malaysia Bangi. 
Duval-Couetil, N., Reed-Rhoads, T., \& Haghghi, S. (2012). Engineering students and entrepreneurship education: involvement, attitudes and outcomes. International Journal of Engineering Education, 28(2), 425-435.

Jaafar Sahari, Ahmad Kamal Ariffin Mohd Ihsan, Shahrir Abdullah, Shahrum Abdullah, Mohd Zaidi Omar, Dzuraidah Abd Wahab, \& Norhamidi Mohamad. (2009). Kreativiti pelajar dalam penyelesaian masalahkes reka bentuk kejuruteraan mekanik. Seminar Pendidikan Kejuruteraan Kongres Pengajaran dan Alam Bina 2009. Universiti Kebangsaan Malaysia Bangi.

Liebenberg, L., \& Mathews, E. H. (2012). Integrating innovation skills in an introductory engineering design-build course. International Journal of Technology and Design Education, 22(1), 93-113. http://dx.doi.org/10.1007/s10798-010-9137-1

Mohamed Khalid Nordin. (2009). Memantapkan Budaya Keusahawanan Di Kalangan Generasi Baru Melalui Sistem Pendidikan Nasional Dan Pengajian Agama: Gagasan dan Cabaran Merealisasikannya. Kongres Ekonomi Islam Ketiga (KEI-3), 12-15 Januari 2009, Dewan Merdeka, PWTC, Kuala Lumpur.

Mohamed Khalid Nordin. (2012). Pendidikan keusahawanan demi negara maju. Retrieved from http://khalednordin.com

Mohammad Yusof Bin Arshad, \& Siti Hajar Binti Alias. (2011). Tahap kreativiti di kalangan pelajar program sains di Fakulti Pendidikan, Universiti Teknologi Malaysia. Universiti Teknologi Malaysia Institutional Repository. Retrieved from http://eprints.utm.my/11891/

Nor Aishah Buang. (2008). Kajian keperluan pendidikan keusahawanan secara formal dalam kalangan pelajar Fakulti Kejuruteraan \& Alam Bina dan Fakulti Pendidikan, UKM. Retrieved from http://www.ukm.my/p3k/images/sppb08/d/7.pdf

Radharamanan, R., \& Juang, J. N. (2012). Innovation and entrepreneurship in engineering education at MUSE. Journal of the Chinese Institute of Engineers, 35(1), 25-36. http://dx.doi.org/10.1080/02533839.2012.624797

Sandberg, K. W., \& Ohman, G. (2011). Learning in innovation development. Procedia - Social and Behavioral Sciences, 28, 379-383. http://dx.doi.org/10.1016/j.sbspro.2011.11.072

Shahrom Md Zain, Noor Ezlin Ahmad Basri, Fatihah Suja, Othman Jaafar, \& Hassan Basri. (2008). Pendidikan alam sekitar: Bagaimana usaha-usaha dilakukan dalam proses pengajaran dan pembelajaran. Seminar Pendidikan Kejuruteraan \& Alam Bina 2008. Universiti Kebangsaan Malaysia Bangi.

Shahrom Md Zain, Noor Ezlin Ahmad Basri, Hassan Basri, Rahmah Elfithri, Azimin Samsul Mohd Tazilan, Maisarah Ahmad, \& Ismi Azura Istear Khan. (2010). Modal insan minda lestari. Kongres Pengajaran dan Pembelajaran UKM 2010, Universiti Kebangsaan Malaysia Bangi.

Shahrom Md Zain, Noor Ezlin Ahmad Basri, Hassan Basri, Rahmah Elfithri, Azimin Samsul Mohd Tazilan, Maisarah Ahmad, \& Ismi Azura Istear Khan. (2011). The enhancement of sustainable humanitarian mind model by UKM Lestari program. Procedia Social and Behavioural Sciences - Kongres Pengajaran dan Pembelajaran UKM 2010, 18, 666-673.

Shahrom Md Zain, Wan Hamidon Wan Badaruzzaman, Rahmah Elfitri, Azami Zaharim, Nuraini Khatimin, Noor Ezlin Ahmad Basri, \& Fatihah Suja'. (2009). Pendidikan lestari: kaji selidik dalam proses pengajaran dan pembelajaran di Fakulti Kejuruteraan \& Alam Bina UKM. Seminar Pendidikan Kejuruteraan \& Alam Bina 2009. Universiti Kebangsaan Malaysia Bangi.

Siti Hawa Mohamed Idris. (2009). Kecenderungan keusahawanan di kalangan pelajar bidang kejuruteraan di Institusi Pengajian Tinggi Awam di kawasan utara semenanjung Malaysia. Tesis Sarjana Sains Pengurusan. Kolej Perniagaan, Universiti Utara Malaysia.

UKM News Portal. (2012). Innovations for consumer products developed by ukm students. Retrieved June 13, 2012, from http://www.ukm.my/news/index.php/en/research-news/1099

Yahaya Buntat, \& Noor Sharliana Mat Nasir. (2011). Faktor-faktor yang mendorong kreativiti di kalangan pelajar, Universiti Teknologi Malaysia. Journal of Educational Psychology and Counseling, 2, 175-208.

Zaini Ujang. (2009). Minda lestari: Pembangunan negara dan pemuliharaan alam sekitar. Universiti Teknologi Malaysia. Johor Darul Ta'zim.

Zaini Ujang. (2010). Budaya inovasi: Prasyarat model baru ekonomi. Universiti Teknologi Malaysia. Johor Darul Ta'zim. 